\title{
Positive Correlation between Dietary Intake of Sodium and Balances of Calcium and Magnesium in Young Japanese Adults -Low Sodium Intake Is a Risk Factor for Loss of Calcium and Magnesium-
}

\author{
Mamoru Nishimuta ${ }^{1}$, Naoko KodAmA ${ }^{1,2}$, Eiko MorIKUnI ${ }^{1}$, Yayoi H. YoshioKA ${ }^{1}$, \\ Nobue MATSUZAKI ${ }^{1}$, Hidemaro TAKEYAMA ${ }^{1,3}$, Hideaki YAMADA ${ }^{1,4}$ and Hideaki KitajImA ${ }^{1,5}$ \\ ${ }^{1}$ Laboratory of Mineral Nutrition, Division of Human Nutrition, The Incorporated Administrative Agency of \\ Health and Nutrition, 1-23-1 Toyama, Shinjuku-ku, Tokyo 162-8636, Japan \\ ${ }^{2}$ Medical University of Yamanashi, 1110 Shimokato, Tamaho-machi, \\ Nakakoma-gun, Yamanashi 409-3898, Japan \\ ${ }^{3}$ Nagoya City University Graduate School of Medical Science, 1 Kawasumi, Mizuho-machi, \\ Mizuho-ku, Nagoya, Aichi 467-8601, Japan \\ ${ }^{4}$ Mimasaka Women's University, 32 Kamikawara, Tsuyama, Okayama 708-0002, Japan \\ ${ }^{5}$ Taisho Pharmaceutical Co. Ltd., 3-24-1 Takata, Toshima-ku, Tokyo 170-8633, Japan
}

(Received March 2, 2004)

\begin{abstract}
Summary The content of calcium (Ca) and magnesium (Mg) in sweat during exercise is considerably higher during a relatively low intake of sodium $(\mathrm{Na})$ of $100 \mathrm{mmol} / \mathrm{d}$ than with an intake of $170 \mathrm{mmol} / \mathrm{d}$. For this reason and also because $\mathrm{Ca}$ and $\mathrm{Mg}$ have a negative balance with a Na intake of $100 \mathrm{mmol} / \mathrm{d}$, we analyzed the relationship between $\mathrm{Na}$ intake and balances of $\mathrm{Ca}$ and $\mathrm{Mg}$ in data from 11 balance studies. From 1986 to 2000, 109 volunteers ( 23 males, 86 females) with an age range of 18 to $28 \mathrm{y}$ took part in mineral balance studies. The balance periods ranged from 5 to $12 \mathrm{~d}$. In a given experiment, the diet of each subject contained the same quantity of food, although this varied between experiments, and was supplied during the balance period without consideration of body weight. In the data of all the studies ( $n=109$ ), the balances of $\mathrm{Ca}$ and $\mathrm{Mg}$ did not correlate positively with $\mathrm{Na}$ intake. However, when the data of the highest $\mathrm{Na}$ study were excluded, the balances of $\mathrm{Ca}$ and $\mathrm{Mg}$ correlated positively with Na Intake. The mean value for the regression equation between $\mathrm{Na}$ intake and $\mathrm{Ca}$ and $\mathrm{Mg}$ balances when the respective balance was equal to zero were, $63.308 \mathrm{mg} \mathrm{Na} / \mathrm{kg} \mathrm{BW} / \mathrm{d}$ (Ca: $\left.n=96, r^{2}=0.134\right)$ and $60.977 \mathrm{mg} \mathrm{Na} / \mathrm{kg} \mathrm{BW} / \mathrm{d}(\mathrm{Mg}: n=96$, $\left.r^{2}=0.268\right)$, respectively. These values are considerably higher than Na requirements estimated by inevitable Na loss. Low dietary Na may therefore be a risk factor for maintaining positive balances of $\mathrm{Ca}$ and $\mathrm{Mg}$.
\end{abstract}

Key Words sodium intake, calcium balance, magnesium balance, estimated average sodium requirement, human

In our previous study (1), we demonstrated unexpected results in the sodium $(\mathrm{Na})$, calcium $(\mathrm{Ca})$, and magnesium $(\mathrm{Mg})$ content of arm sweat of young Japanese females during relatively heavy bicycle ergometer exercise $(1.5 \mathrm{kp}, 50 \mathrm{rpm}, 66 \mathrm{~min}$, twice a day). This exercise was undertaken during a period in which the study participants were consuming a relatively low mineral diet containing dietary $\mathrm{Na}$ of $100 \mathrm{mmol} / \mathrm{d}$ (or sodium chloride $6 \mathrm{~g} / \mathrm{d}$ ). The Na content was lower and $\mathrm{Ca}$ and $\mathrm{Mg}$ content markedly higher in the sweat during this experiment compared to identical experiments in which dietary $\mathrm{Na}$ intake was $170 \mathrm{mmol} / \mathrm{d}$ (or sodium chloride $10 \mathrm{~g} / \mathrm{d})(2)$.

Although no reasonable hypothesis has yet been made to explain these results, one assumption has been proposed (3). With regard to nutritional aspects, these three minerals are all stored in bone (4), and therefore

E-mail: nisimuta@nih.go.jp when any of these minerals reaches a critically low level in the body it is eluted from the bone, thereby compensating for any shortage. The mechanism of elution of these minerals from the bone has been shown to occur through non-mineral selective osteolysis by macrophages (5). If such a mechanism occurs during Na restriction, it is possible that excess $\mathrm{Ca}$ and $\mathrm{Mg}$ may also be eluted in association with $\mathrm{Na}$ and enter the blood stream, leading to an inevitable reduction in intestinal absorption and increase in urine excretion of these minerals. Recently, we reported evidence of such changes with a negative balance of $\mathrm{Ca}$ and $\mathrm{Mg}$ occurring under relatively low $\mathrm{Na}$ intake (ca. $100 \mathrm{mmol} / \mathrm{d}$ ) in humans (6).

With the assumption that there is a correlation between $\mathrm{Na}$ intake and the balances of $\mathrm{Ca}$ and $\mathrm{Mg}$, it may be suggested that $\mathrm{Na}$ intake will be a factor that may have major effects on the metabolism of these minerals. If this is the case, two estimations of the average 
requirements of $\mathrm{Na}$ may be used for calculating the regression equations of $\mathrm{Na}$ intake and balances of $\mathrm{Ca}$ and Mg. The present study involved further analysis of the data of balance studies conducted in our laboratory to investigate these relationships.

\section{SUBJECTS AND METHODS}

The data analysed are the same as those reported previously (6-13). From 1986 to 2000,109 volunteers (23 males, 86 females), age ranging from 18 to $28 \mathrm{y}$, took part in 11 mineral balance studies after having provided written, informed consent. The ethics committee, established by the National Institute of Health and Nutrition in 1990, approved the studies, which were carried out in a metabolic unit. The clinical details of the subjects, duration of the balance studies, calculated daily intakes of energy, protein and fat, and measured dietary intakes of minerals ( $\mathrm{Na}, \mathrm{K}, \mathrm{Ca}$ and $\mathrm{Mg}$ ) are shown in Table 1.

The balance periods ranged from 5 to $12 \mathrm{~d}$, with adaptation periods of 2-4 d. In a given experiment, the diet of each subject contained the same quantity of food, although this varied between experiments and was supplied during the balance period without consideration of body weight. However, small changes to the diet were carried out during the adaptation period in order to ensure that all the food supplied had been consumed.

The subjects ingested an indigestible fecal marker (Carmine $0.3 \mathrm{~g}$ : Merck KGaA, Germany) just before breakfast in the morning, at the beginning and end of the balance period.

In one study (No. 4, Table 1), magnesium oxide (180 $\mathrm{mg}$ as $\mathrm{Mg}$ ) was added to the low $\mathrm{Mg}$ diet, which had no adverse or favourable effects on balance of $\mathrm{Mg}$ (9). In six studies (Nos. $1-3,8-10, n=49$, Table 1), sweat from the arm was collected during exercise on a bicycle ergometer in order to estimate loss of the elements from sweating. The foodstuffs used in each study were selected from those commercially available, with the dietary menus designed by a registered dietician so that they met the dietary allowances in Japan (14), with the exception of the low calcium studies (Nos. 6 and 7 , Table 1) in which food composition tables were used (15). The minerals present in the diet [Na, potassium (K), Ca and $\mathrm{Mg}$ ], feces, urine and sweat ( $\mathrm{Na}, \mathrm{Ca}, \mathrm{Mg}$ ) were measured by the use of an atomic absorption spectrophotometer (Varian AA-5, Australia). Details of these methods have been described previously $(6,11$, 13). Statistical analyses were carried out using StatView-J5.0.

The indicators used in this paper are defined as follows:

Apparent absorption $=[($ Intake $)-($ Fecal output $)](\mathrm{mg} /$ $\mathrm{kg} \mathrm{BW} / \mathrm{d}$ )

Apparent absorption $(\%)=[($ Intake $)-($ Fecal output $)] /$ (Intake) $\times 100(\%)$

Balance $=($ Intake $)-[($ Fecal output $)+($ Urine output $)+$ $\left.(\text { Sweat loss })^{*}\right](\mathrm{mg} / \mathrm{kg} \mathrm{BW} / \mathrm{d})$

*Only when sweat loss during exercise was estimated.

\section{RESULTS}

The results of the study in which $\mathrm{Na}$ intake was the highest of all the studies (Na intake $6.87 \mathrm{~g} / \mathrm{d}$, ca. $300 \mathrm{mmol} / \mathrm{d}$ ) showed an apparent positive $\mathrm{Na}$ balance (7). In contrast, the results from the study in which $\mathrm{Na}$

Table 1. Subjects and dietary intake of energy and minerals.

\begin{tabular}{|c|c|c|c|c|c|c|c|c|c|c|}
\hline \multirow{3}{*}{$\begin{array}{l}\text { Exp. } \\
\text { No. }\end{array}$} & \multirow{3}{*}{ Sex } & \multirow{3}{*}{$\begin{array}{l}\text { Subjects } \\
\text { (n) }\end{array}$} & \multirow{3}{*}{$\begin{array}{l}\text { Duration } \\
\text { (d) }\end{array}$} & \multirow{3}{*}{$\begin{array}{c}\text { Energy } \\
\text { (kcal/d) }\end{array}$} & \multirow{3}{*}{$\begin{array}{l}\text { Protein } \\
\text { (g/d) }\end{array}$} & \multirow{3}{*}{$\begin{array}{c}\text { Fat } \\
(\% \text { of energy) }\end{array}$} & \multicolumn{4}{|c|}{ Intake of minerals } \\
\hline & & & & & & & $\mathrm{Na}$ & $\mathrm{K}$ & $\mathrm{Ca}$ & $\mathrm{Mg}$ \\
\hline & & & & & & & \multicolumn{2}{|c|}{$(\mathrm{g} / \mathrm{d})$} & \multicolumn{2}{|c|}{$(\mathrm{mg} / \mathrm{d})$} \\
\hline 1 & f & 6 & 10 & 1,950 & 89 & 25 & 2.21 & 2.71 & 802 & $283^{\#}$ \\
\hline 2 & $\mathrm{f}$ & 7 & 8 & 1,800 & 76 & 26 & 3.06 & 2.20 & 653 & $216^{\#}$ \\
\hline 2 & $\mathrm{f}$ & 2 & 8 & 1,800 & 76 & 26 & 3.06 & 2.20 & 653 & 216 \\
\hline 3 & f & 8 & 8 & 1,700 & 69 & 25 & 3.08 & 2.20 & 671 & $243^{\#}$ \\
\hline 4 & $\mathrm{~m}$ & 5 & 10 & 2,150 & 71 & 24 & 3.20 & 1.96 & 676 & $334^{*}$ \\
\hline 4 & $\mathrm{~m}$ & 5 & 10 & 2,150 & 71 & 24 & 3.20 & 1.96 & 676 & 154 \\
\hline 5 & $\mathrm{f}$ & 12 & 10 & 1,650 & 65 & 35 & 3.27 & 2.06 & 495 & 194 \\
\hline 6 & $\mathrm{f}$ & 11 & 8 & 1,900 & 66 & 35 & 3.40 & 1.86 & 347 & $186^{\Phi}$ \\
\hline 7 & f & 12 & 8 & 1,850 & 64 & 33 & 3.45 & 1.83 & 294 & $188^{\$}$ \\
\hline 8 & $\mathrm{f}$ & 8 & 12 & 1,750 & 78 & 25 & 3.69 & 2.47 & 719 & $279^{\#}$ \\
\hline 9 & $f$ & 12 & 8 & 1,550 & 75 & 38 & 3.90 & 2.55 & 672 & $261^{\#}$ \\
\hline 10 & $\mathrm{f}$ & 8 & 12 & 1,950 & 87 & 27 & 4.06 & 2.68 & 629 & $261^{\#}$ \\
\hline 11 & $\mathrm{~m}$ & 13 & 5 & 3,250 & 136 & 28 & 6.87 & 3.61 & 1,131 & 379 \\
\hline Total & & 109 & & & & & & & & \\
\hline
\end{tabular}

Energy, protein and fat are calculated values, while minerals are measured ones.

* $\mathrm{Mg}(180 \mathrm{mg} / \mathrm{d})$ was added to the diet as magnesium oxide $(\mathrm{MgO})$.

${ }^{\$}$ Low calcium study.

${ }^{\#}$ Mineral lost during exercise was estimated $(n=49)$. 
Table 2. Correlation coefficients $\left(r^{2}\right)$ between $\mathrm{Na}$ intakes and metabolic indicators (lines) of $\mathrm{Ca}$ and $\mathrm{Mg}$.

\begin{tabular}{|c|c|c|c|c|c|c|c|c|c|}
\hline & \multirow{2}{*}{$\begin{array}{l}\text { Sample } \\
\text { (number) }\end{array}$} & \multirow{2}{*}{$\begin{array}{l}\text { Na intake (range) } \\
(\mathrm{mg} / \mathrm{kg} \mathrm{BW} / \mathrm{d})\end{array}$} & \multirow{2}{*}{$\begin{array}{l}\text { Ca intake (range) } \\
\text { (mg/kg BW/d) }\end{array}$} & \multicolumn{6}{|c|}{$\mathrm{Ca}$} \\
\hline & & & & & Intake & AA & $\mathrm{AA}(\%)$ & Urine & Balance \\
\hline \multirow[t]{5}{*}{ Na intake } & $n=109$ & $38.56-142.23$ & $4.83-23.58$ & $r^{2}$ & $0.416^{* * *}$ & $0.213^{* * *}$ & $0.000 \mathrm{NS}$ & $0.169^{* * *}$ & $0.025 \mathrm{NS}$ \\
\hline & $n=96$ & $38.56-96.40$ & $4.83-16.90$ & & $0.015 \mathrm{NS}$ & $0.111^{* * *}$ & $0.069^{* *}$ & $0.000 \mathrm{NS}$ & $0.134^{* * *}$ \\
\hline & $n=90$ & $43.71-96.40$ & $4.83-15.07$ & & $0.143^{* * *}$ & $0.163^{* * *}$ & $0.038 \mathrm{NS}$ & $0.109^{* *}$ & $0.047^{*}$ \\
\hline & \multirow{2}{*}{$\begin{array}{l}\text { Sample } \\
\text { (number) }\end{array}$} & \multirow{2}{*}{$\begin{array}{l}\text { Na intake (range) } \\
(\mathrm{mg} / \mathrm{kg} \mathrm{BW} / \mathrm{d})\end{array}$} & \multirow{2}{*}{$\begin{array}{l}\text { Mg intake (range) } \\
(\mathrm{mg} / \mathrm{kg} \mathrm{BW} / \mathrm{d})\end{array}$} & \multicolumn{6}{|c|}{$\mathrm{Mg}$} \\
\hline & & & & & Intake & $\mathrm{AA}$ & $\mathrm{AA}(\%)$ & Urine & Balance \\
\hline \multirow[t]{3}{*}{ Na intake } & $n=109$ & $38.56-142.23$ & $2.44-7.83$ & $r^{2}$ & $0.489^{* * *}$ & $0.274^{* * *}$ & $0.020 \mathrm{NS}$ & $0.242^{* * *}$ & $0.029 \mathrm{NS}$ \\
\hline & $n=96$ & $38.56-96.40$ & $2.44-6.42$ & & $0.124 * * *$ & $0.239 * * *$ & $0.032 \mathrm{NS}$ & $0.015 \mathrm{NS}$ & $0.268^{* * *}$ \\
\hline & $n=90$ & $43.71-96.40$ & $2.44-6.42$ & & $0.373^{* * *}$ & $0.316^{* * *}$ & $0.003 \mathrm{NS}$ & $0.104^{* *}$ & $0.199^{* * *}$ \\
\hline
\end{tabular}

AA: apparent absorption.

${ }^{*} p<0.05,{ }^{* *} p<0.01,{ }^{* *} p<0.001$. NS: not significant.
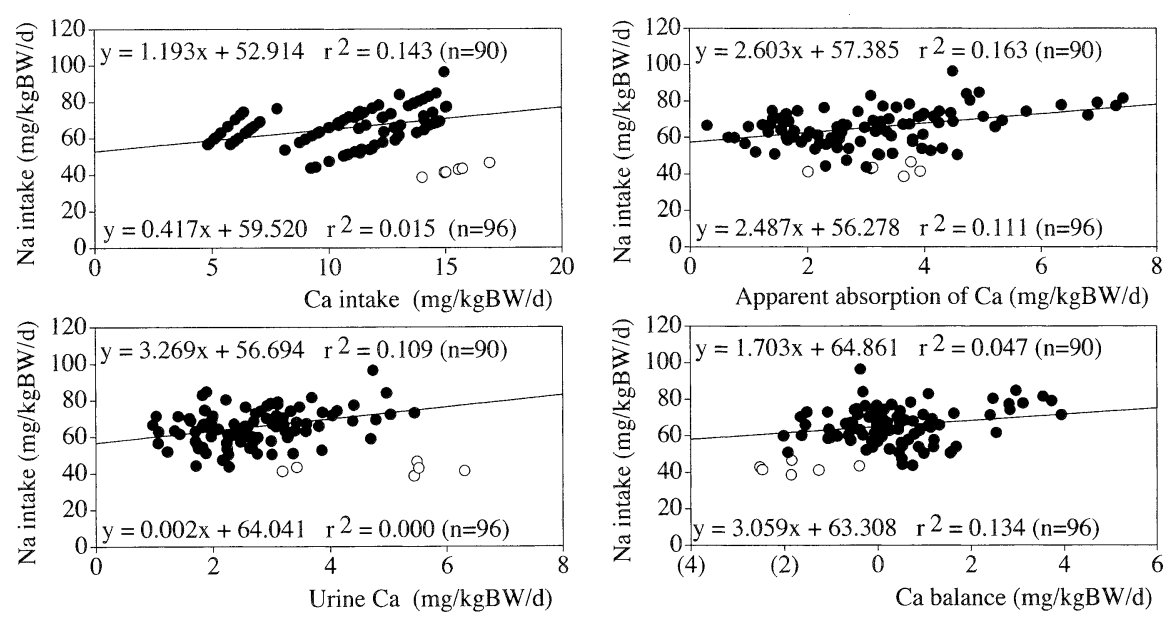

Fig. 1. Relations between Na intake and metabolic indicators (intake, apparent absorption, urine and balance) of Ca in Japanese young adults ( $n=96$ or 90). Data of the highest Na intake study (No. 11, Table 1) were omitted in these figures. Data of the lowest $\mathrm{Na}$ intake study are shown as open circles. Regression lines were obtained without the lowest Na intake study $(n=90)$.

intake was the lowest of all the studies $(2.21 \mathrm{~g} / \mathrm{d}$, ca. $100 \mathrm{mmol} / \mathrm{d}$ ) showed an apparent negative Na balance (6). These data appeared to be different from the remainder of the studies and therefore the regression equations were calculated in the following three ways: all 11 studies $(n=109)$; the 10 studies that did not include the highest Na study $(n=96)$; and the 9 studies that did not include the highest and lowest Na studies $(n=90)$.

The correlation coefficients $\left(r^{2}\right)$ between the dietary intakes of $\mathrm{Na}$ and metabolic indicators of $\mathrm{Ca}$ and $\mathrm{Mg}$ [intake, apparent absorption (AA), urinary excretion (urine) and balance] are shown in Table 2, grouped according to data used in the analyses as described above. In the data of the combined studies $(n=109)$, the balances of $\mathrm{Ca}$ and $\mathrm{Mg}$ were not correlated positively with $\mathrm{Na}$ intake, whereas in the data that excluded the highest $\mathrm{Na}$ study $(n=96)$ or the highest and lowest $\mathrm{Na}$ studies $(n=90)$, the balances of Ca and Mg were correlated positively with $\mathrm{Na}$ intake.

\section{Relationship between $\mathrm{Na}$ intake and indicators of $\mathrm{Ca}$ and $\mathrm{Mg}$ metabolism}

In the data with the highest $\mathrm{Na}$ study excluded $(n=96)$, there was no correlation between $\mathrm{Na}$ intake and intake or urine of $\mathrm{Ca}$, whereas significant correlations existed between $\mathrm{Na}$ intake and $\mathrm{AA}$ and $\mathrm{AA}(\%)$ of $\mathrm{Ca}$. The same data showed a correlation between $\mathrm{Na}$ intake and intake and $\mathrm{AA}$ of $\mathrm{Mg}$ but not with $\mathrm{AA}(\%)$ or urine of $\mathrm{Mg}$. Analysis of the data with the highest and lowest $\mathrm{Na}$ studies excluded $(n=90)$ showed that all four indicators for both $\mathrm{Ca}$ and $\mathrm{Mg}$ with the exception of AAs (\%) correlated positively with $\mathrm{Na}$ intake (Figs. 1 to 3).

Estimated average requirement ( $E A R$ ) of $N$ a calculated from the relationships between $\mathrm{Na}$ intake and $\mathrm{Ca}$ and $\mathrm{Mg}$ balances

No significant correlation between $\mathrm{Na}$ intake and either Ca or $\mathrm{Mg}$ balance was found in the analysis of the data from all 11 studies $(n=109)$. However, the degree of correlation became significant when the data of the highest $\mathrm{Na}$ intake study was excluded $(n=96$ and 

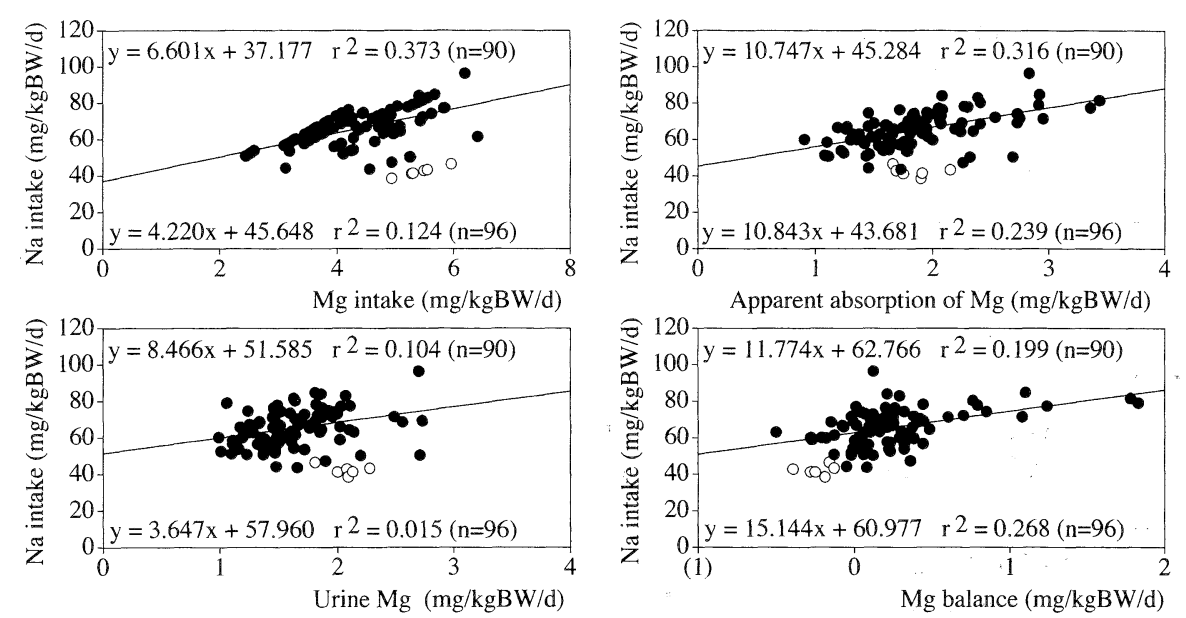

Fig. 2. Relations between $\mathrm{Na}$ intake and metabolic indicators (intake, apparent absorption, urine and balance) of $\mathrm{Mg}$ in Japanese young adults ( $n=96$ or 90). Data of the highest Na intake study (No. 11, Table 1) were omitted in these figures. Data of the lowest Na intake study are shown as open circles. Regression lines were obtained without the lowest Na intake study $(n=90)$.
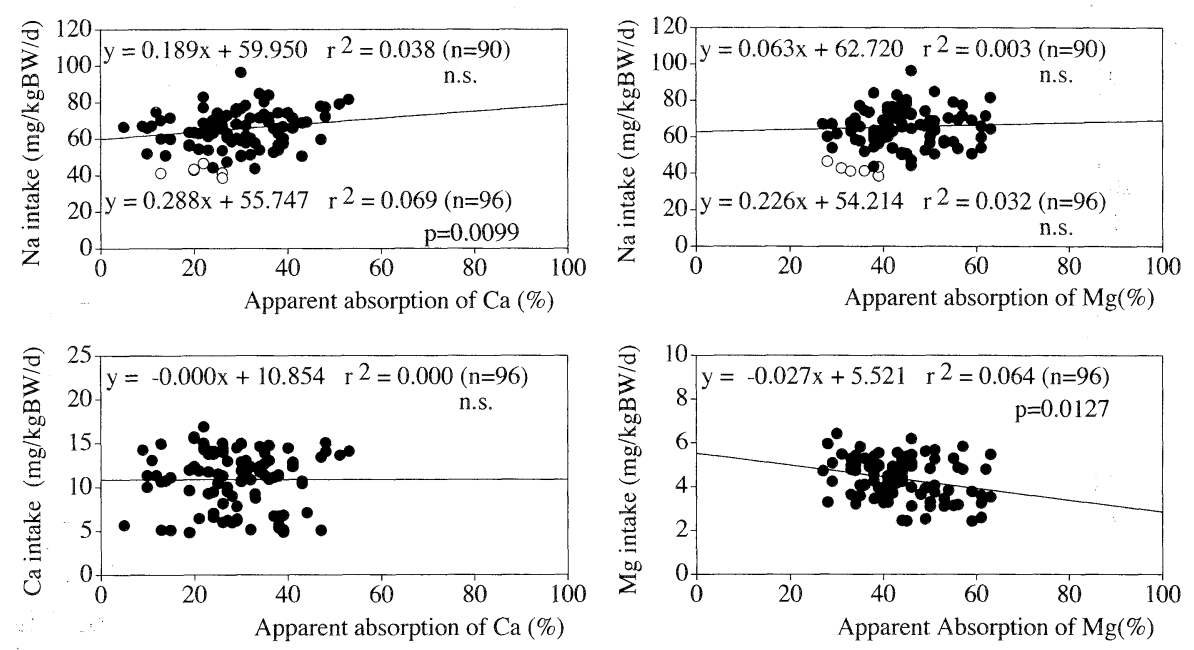

Fig. 3. Relations between apparent absorptions (\%) (AA\%) of $\mathrm{Ca}$ and $\mathrm{Mg}$ and intakes of $\mathrm{Na}$ and respective elements in Japanese young adults $(n=96$ or 90$)$. Data of the highest Na intake study (No. 11, Table 1 ) were omitted in these figures. Data of the lowest $\mathrm{Na}$ intake study are shown as open circles when compared with $\mathrm{Na}$ intake and shown as closed circles when compared with the intakes of the respective minerals. Regression lines between Na intake and AAs (\%) were obtained with 90 data while those between the intakes and AAs (\%) of the respective minerals were from 96 data. Na intake is positively correlated to $\mathrm{AA} \%$ of $\mathrm{Ca}$ when the data of the lowest $\mathrm{Na}$ study are included in the analysis. Ca intake is not correlated to its $\mathrm{AA} \%$. AA\% of $\mathrm{Mg}$ is not correlated to $\mathrm{Na}$ intake but to $\mathrm{Mg}$ intake.

$n=90$ ) as shown in Figs. 1 and 2. The mean value and upper and lower limits of the $95 \%$ confidence interval for the regression equation between $\mathrm{Na}$ intake and $\mathrm{Ca}$ and $\mathrm{Mg}$ balances when the respective balance was equal to zero were, $64.861,62.784,66.973 \mathrm{mg} \mathrm{Na} / \mathrm{kg}$ BW/d (Ca: $\left.n=90, r^{2}=0.047\right), 63.308,61.172,65.444$ $\mathrm{mg} \mathrm{Na} / \mathrm{kg} \mathrm{BW} / \mathrm{d} \quad\left(\mathrm{Ca}: n=96, \quad r^{2}=0.134\right), 62.766$, $60.578, \quad 64.953 \mathrm{mg} \mathrm{Na} / \mathrm{kg} \mathrm{BW} / \mathrm{d} \quad\left(\mathrm{Mg}: \quad n=90, \quad r^{2}=\right.$ $0.199)$ and $60.977,58.783,63.170\left(\mathrm{Mg}: n=96, r^{2}=\right.$ $0.268) \mathrm{mg} \mathrm{Na} / \mathrm{kg} \mathrm{BW} / \mathrm{d}$, respectively.

\section{DISCUSSION}

This study on mineral balance data of 109 subjects is the first report on the relationship between dietary $\mathrm{Na}$ intake and $\mathrm{Ca}$ and $\mathrm{Mg}$ balances in young Japanese adults.
Positive correlation between $\mathrm{Na}$ intake and $\mathrm{Ca}$ and $\mathrm{Mg}$ balances

Several studies have reported that high intake of $\mathrm{Na}$ increases not only urinary $\mathrm{Na}$ but also urinary $\mathrm{Ca}$ excretion (16). However, these data did not take into account the changes in apparent absorption of $\mathrm{Ca}$ caused by the increase in $\mathrm{Na}$ intake. As a consequence of this omission high Na intake was regarded as a factor in the loss of body Ca. In contrast, the present study demonstrated positive correlations between $\mathrm{Na}$ intake and $\mathrm{Ca}$ and $\mathrm{Mg}$ balances within limited ranges of $\mathrm{Na}$ intake. This indicates that low Na intake decreases the absorption of both $\mathrm{Ca}$ and $\mathrm{Mg}$, leading to a reduction in the urine excretions of both minerals. This effect was not apparent in our study of the lowest Na intake with this data showing increases in urine excretion of $\mathrm{Ca}$ and 
$\mathrm{Mg}$ despite apparent absorption of these minerals being decreased (6). When Na status reaches a critically low level in the body, $\mathrm{Na}$ is eluted from the bone in order to compensate for any shortage. Under these conditions Ca and Mg may also be eluted from bone leading to an increase in urine excretion of both minerals.

As there was a strong correlation between apparent absorption and urinary excretion of both $\mathrm{Ca}$ and $\mathrm{Mg}$ (11), low dietary $\mathrm{Na}$ intake may therefore be a risk factor for maintaining positive balances of $\mathrm{Ca}$ and $\mathrm{Mg}$.

In a previous study we found that $\mathrm{Na}$ intake correlated positively with $\mathrm{Na}$ balance only when the data of the study with the highest $\mathrm{Na}$ intake was included in the analysis (13). Na intake of $300 \mathrm{mmol} / \mathrm{d}$ may be excessive and require an alternative mechanism for excretion of $\mathrm{Na}$ into the urine. The estimated average requirement (EAR) of $\mathrm{Na}$ can be determined based on the relationship between $\mathrm{Na}$ intake and $\mathrm{Ca}$ and $\mathrm{Mg}$ balances, as within the range where $\mathrm{Na}$ intake is not correlated with $\mathrm{Na}$ balance, $\mathrm{Na}$ intake is correlated positively with both $\mathrm{Ca}$ and $\mathrm{Mg}$ balances.

Estimated average requirement of $\mathrm{Na}$

The mean values for the regression equation between $\mathrm{Na}$ intake and $\mathrm{Ca}$ and $\mathrm{Mg}$ balances when the respective balance was equal to zero were, $64.861 \mathrm{mg} \mathrm{Na} / \mathrm{kg} \mathrm{BW/}$ $\mathrm{d}\left(\mathrm{Ca}: n=90, r^{2}=0.047\right), 63.308 \mathrm{mg} \mathrm{Na} / \mathrm{kg} \mathrm{BW} / \mathrm{d}(\mathrm{Ca}:$ $\left.n=96, r^{2}=0.134\right), 62.766 \mathrm{mg} \mathrm{Na} / \mathrm{kg} \mathrm{BW} / \mathrm{d}(\mathrm{Mg}: n=$ 90, $\left.r^{2}=0.199\right)$ and $60.977 \mathrm{mg} \mathrm{Na} / \mathrm{kg} \mathrm{BW} / \mathrm{d}(\mathrm{Mg}: n=$ $\left.96, r^{2}=0.268\right)$, respectively. These values are equivalent to the estimated average requirements (EARs) of Na.

In a previous analysis we reported a significant correlation between $\mathrm{Na}$ intake and $\mathrm{Na}$ balance in the data of all 11 studies $(n=109)$. The mean value and upper and lower limits of the $95 \%$ confidence interval for the regression equation between intake and balance for $\mathrm{Na}$, when $\mathrm{Na}$ balance was equal to zero, were 55.824 , 60.787 and $50.862 \mathrm{mg} \mathrm{Na} / \mathrm{kg} \mathrm{BW} / \mathrm{d}$, respectively $\left(r^{2}=\right.$ $0.361)$ (13). These values are considerably higher than the $\mathrm{Na}$ requirement estimated by inevitable $\mathrm{Na}$ loss (16). However, this correlation was not significant when the data of the highest $\mathrm{Na}$ intake study was excluded ( $n=96$ and $n=90$ ) (13). Thus, the EAR of Na, as the value for maintaining a positive $\mathrm{Na}$ balance should not be considered as the definitive value.

In this study, there was a positive correlation between $\mathrm{Na}$ intake and the balances of both $\mathrm{Ca}$ and $\mathrm{Mg}$ when the data of the highest Na intake study was excluded $(n=96$ and $n=90$ ). The EARs calculated in the present study are higher than those obtained in our Na study (13). However, the data used in this analysis showed there was no correlation between $\mathrm{Na}$ intake and $\mathrm{Na}$ balance.

If the EARs of $\mathrm{Na}$ are used as the values for maintaining a positive balance of $\mathrm{Ca}$ and $\mathrm{Mg}$, this equates to $60-$ $63 \mathrm{mg} \mathrm{Na} / \mathrm{kg} \mathrm{BW} / \mathrm{d}$. Therefore EAR for adult Japanese aged $30-49 \mathrm{y}$ are $4.08-4.28 \mathrm{~g} \mathrm{Na} / \mathrm{d}$ (10.4-10.9 g $\mathrm{NaCl} / \mathrm{d}$ or $178-186 \mathrm{mmol} / \mathrm{d}$ ) for males (height 170.0 $\mathrm{cm}$, weight $68.0 \mathrm{~kg})$ and $3.16-3.32 \mathrm{~g} \mathrm{Na} / \mathrm{d}(8.0-8.4 \mathrm{~g}$ $\mathrm{NaCl} / \mathrm{d}$ or $137-144 \mathrm{mmol} / \mathrm{d}$ ) for females (height 156.8 $\mathrm{cm}$, weight $52.7 \mathrm{~kg})(17)$.
In this paper, we reported the upper and lower limits of the $95 \%$ confidence interval for the regression equations between $\mathrm{Na}$ intake and $\mathrm{Ca}$ and $\mathrm{Mg}$ balances when the balances of $\mathrm{Ca}$ and $\mathrm{Mg}$ were equal to zero. However, these values are not the same as those used in the United States of America to determine the recommended dietary allowance for $\mathrm{Na}(18)$. The statistical value of $\mathrm{Na}$ intake that resulted in $97.5 \%$ of population maintaining positive balances of $\mathrm{Ca}$ and $\mathrm{Mg}( \pm 2 \mathrm{SD})$ may be difficult to find experimentally and may not even exist. Instead of this value, upper limits of the 95\% confidence interval for the regression equation between $\mathrm{Na}$ intake and $\mathrm{Ca}$ and $\mathrm{Mg}$ balances when the respective balance was equal to zero will be proposed for recommended dietary allowance for $\mathrm{Na}$ as scientific values.

Although excess salt $(\mathrm{NaCl})$ intake is an important etiological factor in salt sensitive hypertension, it has not been determined how much is excessive or whether short intakes of $\mathrm{Na}$ results in increases in blood pressure. In our previous study (13) as well as in this study, we showed $\mathrm{Na}$ intake affected the balances of $\mathrm{Na}, \mathrm{K}, \mathrm{Ca}$ and $\mathrm{Mg}$ with an intake of about 55-65 $\mathrm{mg}$ of $\mathrm{Na}$ per $\mathrm{kg}$ of body weight each day being required to maintain a positive balance of these minerals. This value represents the average $\mathrm{Na}$ requirement and corresponds to the borderline between short and adequate but is beyond the borderline between adequate and excess for the dietary reference intakes (DRIs) of $\mathrm{Na}(17,18)$. Our results may therefore explain the higher incidence of ischemic heart diseases and bone fracture in Western countries compared to those in Japan. Further studies and discussion will, however, be needed to establish the DRIs for $\mathrm{Na}$ and to clarify the relation between $\mathrm{Na}$ status and etiology of diseases.

In conclusion, we found positive correlations between $\mathrm{Na}$ intake and $\mathrm{Ca}$ and $\mathrm{Mg}$ balances in humans. Using the mean values for the regression equation between $\mathrm{Na}$ intake and balances of $\mathrm{Ca}$ and $\mathrm{Mg}$ we calculated a preliminary estimated average requirement for $\mathrm{Na}$ of $60-63 \mathrm{mg} \mathrm{Na} / \mathrm{kg} \mathrm{BW} / \mathrm{d}$.

\section{Acknowledgments}

We thank the volunteers who graciously gave their time and effort to these studies.

MN and NK designed the studies. MN, NK, EM, YHY, NM, HT, HY and HK conducted the human metabolic studies and analyzed data. MN wrote the manuscript. MN received grant funding from the Environmental Agency, Health Science Foundation, Uehara Memorial Foundation, the Salt Science Research Foundation (Japan) and the Ministry of Health, Labor and Welfare. None of the authors had a conflict of interest.

\section{REFERENCES}

1) Nishimuta M, Kodama N, Ono K, Kobayashi S, Suzuki K. 1985. Mineral contents in arm sweat at a low mineral diet with special reference to the onset of physical exercise. J Jap Soc Mg Res (JJSMgR) 4: 13-21 (in Japanese).

2) Nishimuta M, Kodama N, Takeyama H, Toyooka F. 
1997. Magnesium metabolism and physical exercise in human. In: Magnesium: Current Status and New Development (Theophanides T, Anastassopoulou J, eds), p 109-113. Kluwer Academic Publishers, Dordrecht.

3) Nishimuta M. 1990. The concept (intra and extra cellular minerals). In: Metal Ions in Biology and Medicine (Collery P, Poirier LA, Manfait M, Etienne J-C, eds), p 69-74. John Libbey Eurotext, Paris.

4) Ishizaki A. 1974. Mineral metabolism. In: Handbook in Nutrition, p 605-657. Gihoudou, Tokyo (in Japanese).

5) Kumegawa M. 1993. Formation and function of osteoclast. Molec Med 30: 1240-1247 (in Japanese).

6) Kodama N, Nishimuta M, Suzuki K. 2003. Negative balance of calcium and magnesium under a relatively low sodium intake in human. J Nutr Sci Vitaminol 49: 201209.

7) Nishimuta M, Kodama N, Hitachi Y, Ozawa M, Ahmed SM, Oomori T. 1991. A mineral balance study in male long distance runners. J Jap Soc Mg Res (JJSMgR) 10: 243-253 (in Japanese).

8) Nishimuta M, Kodama N. 1993. Magnesium balances studies in young Japanese. J Jap Soc Mg Res (JJSMgR) 12: 29-37 (in Japanese).

9) Takeyama H, Kodama N, Fuchi T, Nishimuta M. 1997. Magnesium, calcium and phosphorus balances in young males at low dietary magnesium levels with or without magnesium supplementation. In: Advances in Magnesium Research: 1 (Smetana R, ed), p 355-363. John Libbey \& Co Ltd, London.

10) Nishimuta M, Kodama N, Yoshioka YH, Morikuni E. 2001. Magnesium intake and balance in the Japanese population. In: Advances in Magnesium Research: Nutrition and Health (Rayssiguier Y, Mazur A, Durlach
J, eds), p 197-200. John Libbey \& Co Ltd, London.

11) Nishimuta $M$, Kodama N, Morikuni E, Yoshioka YH, Takeyama H, Yamada H, Kitajima H, Suzuki K. 2004. Balance of calcium, magnesium and phosphorus in Japanese young adults. J Nutr Sci Vitaminol 50: 19-25.

12) Nishimuta M, Kodama N, Morikuni E, Yoshioka $Y H$, Yamada H, Kitajima H, Takeyama H, Suzuki K. 2004. Balance of magnesium positively correlates with that of calcium-Estimated average requirement of $\mathrm{Mg}-$. J Am Coll Nutr 23: 768S-770S.

13) Kodama N, Morikuni E, Matsuzaki N, Yoshioka YH, Takeyama H, Yamada H, Kitajima H, Nishimuta M. 2005. Sodium and potassium balances in Japanese young adults. J Nutr Sci Vitaminol 51: 161-168.

14) Ministry of Health and Welfare. Dietary Allowances for the Japanese, Third (1984), Fourth (1989), Fifth (1994) and Sixth (1999) revised edition. Daichi Shuppan, Tokyo (in Japanese).

15) Resources Council, Science and Technology Agency, Japan. 1982. Standard Tables of Food Composition in Japan, Fourth revised edition. Ookurashou Insatukyoku, Tokyo (in Japanese).

16) Cirillo M, Ciacci C, Laurenzi M, Mellone M, Mazzacca G, De Santo NG. 1997. Salt intake, urinary sodium, and hypercalciuria. Miner Electrolyte Metab 23: 265-268.

17) Ministry of Health, Labour and Welfare. 2005. Dietary Reference Intakes (DRIs) for the Japanese. (Draft)

18) Food and Nutrition Board, Institute of Medicine. 2004. Sodium and chloride. In: Dietary Reference Intakes for Water, Potassium, Sodium, Chloride, and Sulfate (2004), p 247-349. Internet: http://books.nap.edu/ books/0309091691/html/247.htm (accessed 14 February 2005). 